\title{
E-COHESION: E-SOLUTIONS IN THE IMPLEMENTATION OF COMBINED FINANCIAL INSTRUMENTS
}

\author{
Györgyi Nyikos ${ }^{1}$, Szilvia Hajdu and Tamás Laposa ${ }^{2}$
}

\begin{abstract}
Europe is facing an investment gap and the so-called financial instruments seem to be one of the solutions. They invest public sources on a repayable basis with a revolving character, which allows for a much greater efficiency in the allocation of public capital and the long-term sustainability of public investment. Policymakers see considerable value in supporting the further development of FIs and their use in both existing and new policy-related areas of activity. The combined-credit is a unique financial development tool where credit and non-repayable assistance can be requested within a single financial product. [10,13]
\end{abstract}

The paper analyses the Hungarian practice using this special financial instrument with the application of information technology, both looking at the empirical evidences and seeking for an answer to the question, whether the combined utilization of financial instruments and grants is effective, useful or not, and how the different IT solutions could affect the efficiency of this financial product.

It is argued in this paper that the utilization of information technology can significantly improve the effectiveness of using financial instruments. This paper has three main aims: first, to review the legislation and the approach of Member States on the utilization of financial instruments; second, to analyse current and previous forms of IT support and their impact on the efficient utilization of the above instruments; third, to make proposals for further research on the e-government-based utilization of financial instruments.

Key words: financial instrument, combined-credit.

\section{The relevance of financial instruments and the combination}

Financial instruments ${ }^{4}$ (FIs) [4] provide funding for investments which are expected to be financially viable and do not give rise to sufficient funding from market sources. FIs can take the

\footnotetext{
${ }^{1}$ Dr. Györgyi Nyikos is an Associate Professor, National University of Public Service. Her teaching and research interests are in Public Finance Management, Cohesion Policy and Public Procurement.

${ }^{2}$ National University of Public Administration, Budapest

${ }^{3}$ The recent EU Budget Review as well as the new Investment Plan for Europe noted that FIs could provide an important new financing mechanism for strategic investments by attracting co-investment from other public and private sector sources in order to achieve EU policy goals more efficiently.

${ }^{4}$ Regulation (EU, Euratom) No 966/2012 of the European Parliament and of the Council of 25 October 2012 on the financial rules applicable to the general budget of the Union and repealing Council Regulation (EC, Euratom) No 1605/2002; "financial instruments" means Union measures of financial support provided on a complementary basis from the budget in order to address one or more specific policy objectives of the Union. Such instruments may take the form of equity or quasi-equity investments, loans or guarantees, or other risk-sharing instruments, and may, where appropriate, be combined with grants".
} 
form of loans, guarantees, equity capital or venture capital, using tailor-made instruments, off-theshelf instruments or combined solutions and can be implemented as established at EU level ${ }^{5}$ or at national level ${ }^{6}$. The revolving nature of FIs allows for much greater efficiency in the allocation of public capital and for the long-term sustainability of public investment. By unlocking other public sector funding and private sector resources through co-financing and co-investment, FIs aim to increase the overall capital available. In addition, the private sector participation enables policymakers to make use of private sector skills and expertise in areas such as identifying investments, decision-making, managing commercial operations and the ability to achieve returns.

One of the main advantages of using FIs is the added value that revolving instruments have over grants in terms of the efficient use of public resources. Repayable forms of support can also act as an incentive for better quality investments as the investments need to be economically viable so that the final recipient is able to repay the support provided. Through the Investment Plan for Europe the Commission strongly encourages the use of financial instruments that could replace traditional grants in $\mathrm{ESIF}^{7}$ funding, in areas such as $\mathrm{SME}$ support, $\mathrm{CO} 2$ reduction, environmental and resource efficiency, ICT, sustainable transport and R\&I. [24]

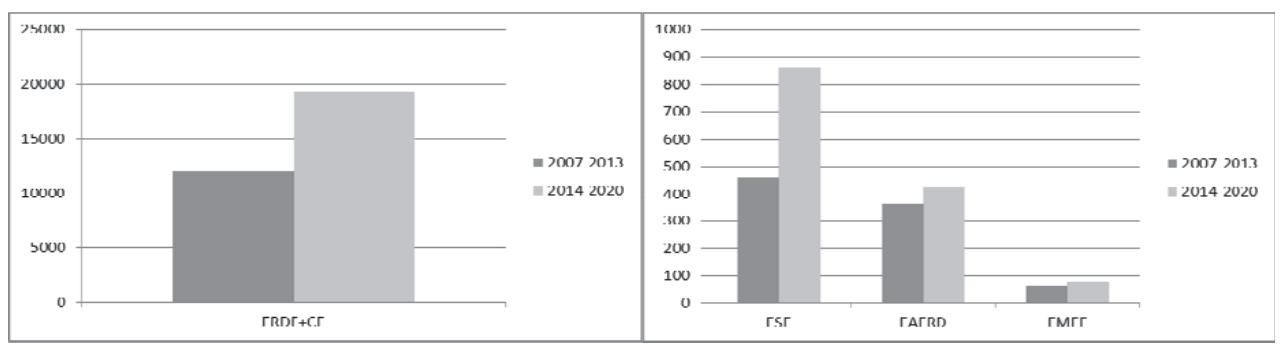

Figure 1: Amount of ESIF funding delivered through financial instruments in 2007-2013 and 2014-2020 (EUR million)

Source: Investing in jobs and growth - maximising the contribution of European Structural and Investment Funds, [12]

A new development in the 2007-2013 programming period was the combined use of financial instruments and grants, partly as an answer or reaction to the financial crisis ${ }^{8}$. However in the 20072013 programming period there were short and limited rules and later few guidance documents on Financial Engineering Instruments (FEIs) without any word about combination. It gave room for manoeuvre for the Member States but also caused legal uncertainty. The regulatory texts on FIs for the 2014-2020 period show that the legislators have attempted to address many of the challenges that have arisen in this programming period in the regulatory provisions and address issues raised

\footnotetext{
${ }^{5}$ managed directly or indirectly by the European Commission (EC)

${ }^{6}$ directly implemented by Managing Authorities (MAs) or via a Holding Fund where the holding fund manager may be the European Investment Bank (EIB), the European Investment Fund (EIF) or other financial institutions or agencies and with financial intermediaries or implemented via financial intermediaries without holding fund

${ }^{7}$ European Structural and Investment Funds

${ }^{8}$ As a consequence of the economic crisis in Hungary it became practically impossible for the SMEs to receive commercial bank loans even for the finance of their own (co-financing) part of the investment supported by grants. To tackle this problem, the objective was to develop the methods of micro-financing and to increase the amount of available resources.
} 
by Managing Authorities (MAs) and the European Court of Auditors ${ }^{9}$, and make possible more types of FI combination than earlier, which facilitates the transition from a financial support regime based on grants towards the use of revolving FIs. [24]

The Common Provisions Regulation $(\mathrm{CPR})^{10}$ makes it clear that more types of combination may be possible $^{11}:[5]$

- combination of different programme contributions and different funds in one financial instrument; and

- $\quad$ combination of financial instruments and grants and other forms of assistance.

The advantage of using the combined solutions can be the achievement of critical mass and economies of scale as well as a wider spectrum of policy objectives. In the "Guidance for Member States and Programme Authorities on Combination of support from a financial instrument with other support" the Commission presented two types of combination of support: within a financial instrument operation (a single operation) and at the level of the final recipient (combination of two separate operations). According to the guidance, grants as technical support, interest rate subsidies and guarantee fee subsidies can be combined with the FI in a single operation if they are directly related to the FI and target the same final recipients. However, separate records must be kept for each form of support. Alternatively, final recipients supported by an ESI Fund FI may also receive assistance from another ESI Fund priority or programme or from another instrument supported by the EU budget. Yet again, separate records shall be maintained for each source of assistance. [24]

In case of launching combined products, it should be taken into account that processes should not be much longer and complicated than in case of regular, single-profiled products (direct grants and assistances with revolving nature).

In the interests of ensuring proportionate control arrangements and of safeguarding the added value of financial instruments, Member States should reduce the administrative burdens of final recipients. Pursuant to the provisions of the above regulation, Member States shall provide electronic government services and offer paperless fund management possibilities to beneficiaries to reduce their administrative burdens.

\footnotetext{
${ }^{9}$ For example, revised provisions relating to the ex-ante evaluations that must be undertaken before FIs are established in the OPs. It has been made clear that ex-ante evaluations will tie the findings related to market gaps more closely into the objectives and priorities of the OPs, and will include more information on what type of financial products should be put in place.

10 Regulation (EU) No 1303/2013 of the European Parliament and of the Council of 17 December 2013 laying down common provisions on the European Regional Development Fund, the European Social Fund, the Cohesion Fund, the European Agricultural Fund for Rural Development and the European Maritime and Fisheries Fund and laying down general provisions on the European Regional Development Fund, the European Social Fund, the Cohesion Fund and the European Maritime and Fisheries Fund and repealing Council Regulation (EC) No 1083/2006.

11 Art. 37(7) CPR
} 


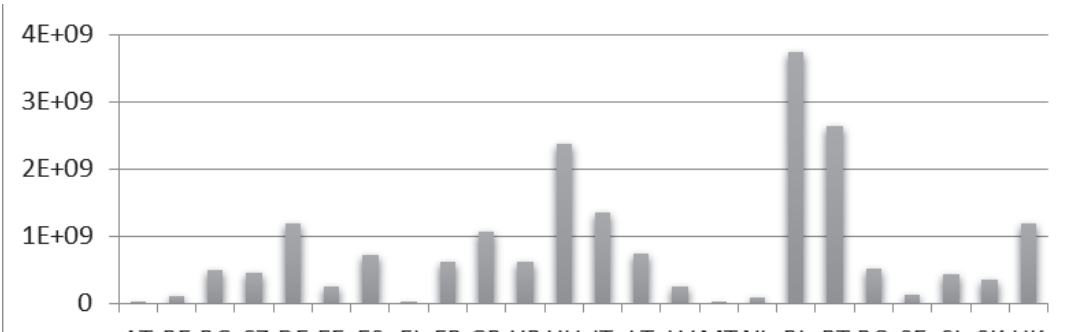

AT BE BG CZ DE EE ES FI FR GR HRHU IT LT LVMT NL PL PT RO SE SI SK UK

Figure 2: FIs in 2014-2020 period (ESIF in EUR)

Source: Nyikos, data from the EC (downloaded on 9. 7. 2016), OPs adopted by EC ${ }^{12}$ [19,20,21,24]

\section{The Hungarian case of combination of credit and grant}

In the 2007-2013 programming period Hungary decided to use FIs in order to provide access to finance for SMEs. According to programme documents and AIR 2013; the main objective of FIs was to overcome the limited access of finance on the market, moreover the idea of introducing financial instruments was strongly driven by the assumption that FIs may represent more efficient forms of SME support than grants. The total amount of FIs set up in proportion of the ERDF support was around $6 \%{ }^{13}$ and mainly the Economic Development Operational Programme financed $\mathrm{FIs}^{14} \cdot[19,22]$

Until the end of 2011 , only $27.91 \%$ of the FI sources had been disbursed to final recipients, but the absorption of resources largely accelerated in the second half of the programme period. The New Hungary Joint Fund (27.62\%), the Combined Microcredit (24.85\%) and the New Széchenyi Loan $(18.14 \%)$ were the top three "products" with the highest share of the allocated funds. [24]

\footnotetext{
${ }^{12}$ Nyikos (2016): Research for REGI Committee - Financial instruments in the 2014-20 programming period: First experiences of Member States, European Union, 2016

13 The financial allocation of the Economic Development Operational Programme's 4th priority (financial instruments) was increased by $3 \%$ in 2009 through Operational Programme (OP) modification.

${ }^{14}$ Economic Development Operational Programme 2007-2013. CCI number: 2007HU161PO001. http://www.nfu.hu /umft_operativ_programok.
} 


\begin{tabular}{|c|c|c|c|c|c|}
\hline Ops & $\begin{array}{l}\text { Budget of } \\
\text { OP } \\
\text { (without } \\
\text { TA) }\end{array}$ & $\begin{array}{l}\text { FI forms in } \\
\text { the } \\
\text { OP }\end{array}$ & $\begin{array}{c}\text { FI budget in the } \\
\text { OP }\end{array}$ & $\begin{array}{l}\text { FI in } \% \\
\text { of the } \\
\text { OP }\end{array}$ & $\begin{array}{l}\text { FI\% of the } \\
\text { total } \\
\text { ERDF }\end{array}$ \\
\hline $\begin{array}{c}\text { Economic Development } \\
\text { Operational Programme 2007-2013 (EDOP) } \\
\text { which covers the convergence regions (6 regions } \\
\text { out of } 7 \text { ) [19] }\end{array}$ & $\begin{array}{l}\text { EUR 3,257 } \\
\text { million }\end{array}$ & $\begin{array}{l}\text { Credit, } \\
\text { Guarantee, } \\
\text { VC }\end{array}$ & $\begin{array}{l}\text { EUR } 727 \text { million } \\
\text { (the total FI } \\
\text { priority axis) }\end{array}$ & $22 \%^{15}$ & $5 \%$ \\
\hline $\begin{array}{c}\text { Central Hungary Operational Programme }{ }^{16} \\
2007-2013 \text { (CHOP) for the Regional } \\
\text { Employment and Competitiveness objective } \\
{[20]}\end{array}$ & $\begin{array}{l}\text { EUR 1,663 } \\
\text { million }\end{array}$ & $\begin{array}{l}\text { Credit, } \\
\text { Guarantee, } \\
\text { VC }\end{array}$ & $\begin{array}{l}\text { ca EUR } 117 \\
\text { million } \\
\text { (FIs cover part of } \\
\text { the } 1^{\text {st }} \text { priority) }\end{array}$ & $7 \%$ & $0.7 \%$ \\
\hline $\begin{array}{c}6 \text { Regional Development Operational } \\
\text { Programmes }{ }^{17} \text { (RDOP) for the Convergence } \\
\text { regions [21] }\end{array}$ & $\begin{array}{l}\text { EUR 4,881 } \\
\text { million }\end{array}$ & $\mathrm{VC}$ & $\begin{array}{l}\text { EUR } 7 \text { million } \\
\text { /OP (in } \\
\text { Strengthening } \\
\text { the region's SME } \\
\text { sector priorities) }\end{array}$ & $0.8 \%$ & $0.3 \%$ \\
\hline \multicolumn{5}{|c|}{ ERDF support between 2007-2013 } & $\begin{array}{l}\text { EUR } 14,44 \\
1 \text { million } \\
6 \%\end{array}$ \\
\hline
\end{tabular}

Table 1: FIs in the OPs in Hungary

Source: Nyikos [22]
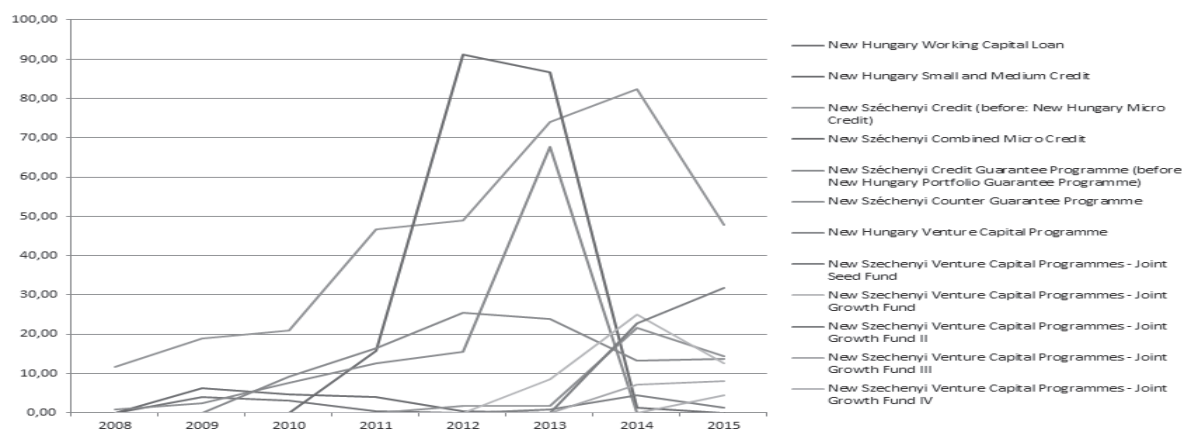

Figure 3: Absorption process of the different Hungarian FIs

Source: Nyikos, data from Fontium, Hungarian Development Bank $2016^{18}$

Loan was the first ${ }^{19}$ financial engineering instrument in Hungary, however since the start the main parameters of the program were changed 3 times as a reaction to the crisis. In 2011 the already functioning loan programmes were supplemented with a new combined loan plus grant scheme. From a state aid point of view, the combined microcredit was granted under the "de minimis" principle $^{20}$, where SMEs could get a maximum $45 \%$ of the project value ${ }^{21}$ as a grant and a

\footnotetext{
${ }^{15} 24 \%$ of EDOP sources, in total EUR 703 million, was finally allocated to FIs by 2014 (KPMG 2013; EDOP AIR 2014; EDOP 2007)

${ }^{16}$ Central Hungary Operational Programme 2007-2013. CCI number: 2007HU162PO001. http://www.nfu.hu/umft_ operativ_programok

${ }^{17}$ Regional Development Operational Programmes 2007-2013. http://www.nfu.hu/umft_operativ_programok

${ }^{18}$ Nyikos (2016): Research for REGI Committee - Financial instruments in the 2014-20 programming period: First experiences of Member States, European Union, 2016

19 The calls for tender for the banks and micro financing institutions were launched in October 2007, while the first contracts with the intermediaries were drawn up in December 2007. In January 2008 the first micro credit transactions were carried out.

${ }^{20}$ Under Commission Regulation (EC) No 1998/2006.

${ }^{21}$ or 10 million HUF
} 
maximum $60 \%$ of the project value $\mathrm{e}^{22}$ as micro credit and the starting point is that they had to contribute with their own resources amounting to $10 \%$ of the total investment. [1] The amount of grant could not exceed the amount of micro credit and application requirements stipulated that applicants had to make $10 \%$ own contribution available, which could not be financed by any other subsidized loan. In the decision process the amount of $10 \%$ own contribution was automatically considered and first the loan amount had to be calculated, and then the remaining gap could be covered as grant in accordance with the conditions of the call. The admission and assessment of loan applications, the disbursement of loans, and the management of loan accounts were carried out by financial intermediaries in a one-stop-shop system but without unified and integrated IT support. [24]

In order to implement the JEREMIE programme in Hungary a widespread external intermediary network was set up. Loans have been offered by three types of financial intermediaries (credit institutions, financial enterprises and local enterprise development agencies).

\begin{tabular}{|c|c|c|c|c|c|c|c|c|c|}
\hline \multirow[b]{2}{*}{ Financial intermediaries } & \multicolumn{5}{|c|}{$\begin{array}{l}\text { Number of agreements concluded with } \\
\text { financial intermediaries }\end{array}$} & \multicolumn{4}{|c|}{ Type of products } \\
\hline & $\begin{array}{l}\text { Dec. } \\
2011\end{array}$ & $\begin{array}{l}\text { Dec. } \\
2012\end{array}$ & $\begin{array}{l}\text { Dec. } \\
2013\end{array}$ & $\begin{array}{l}\text { Dec. } \\
2014\end{array}$ & $\begin{array}{l}\text { Dec. } \\
2015\end{array}$ & Loan & $\begin{array}{l}\text { Combined } \\
\text { microcredit }\end{array}$ & Guarantee & $\begin{array}{l}\text { Venture } \\
\text { capital }\end{array}$ \\
\hline Venture Capital Fund Managers & 8 & 18 & 27 & 28 & 29 & - & - & - & $\mathrm{X}$ \\
\hline Commercial banks & 99 & 116 & 119 & 120 & 120 & $\mathrm{X}$ & - & $\mathrm{X}$ & - \\
\hline Financial enterprises & 53 & 76 & 94 & 97 & 97 & $\mathrm{X}$ & $\mathrm{X}$ & - & - \\
\hline $\begin{array}{l}\text { Saving co-operatives / Co- } \\
\text { operative saving org. }\end{array}$ & 76 & 111 & 134 & 134 & 134 & $\mathrm{X}$ & $\mathrm{X}$ & - & - \\
\hline $\begin{array}{l}\text { Microfinance institutions / } \\
\text { enterprise agencies }\end{array}$ & 35 & 35 & 35 & 35 & 35 & $\mathrm{X}$ & $\mathrm{X}$ & - & - \\
\hline Total & 271 & 356 & 409 & 414 & 415 & & & & \\
\hline
\end{tabular}

Table 2: Types and number of financial intermediaries

Source: Nyikos, figures from the Hungarian Development Bank, 31 December 2013. ${ }^{23}$ [23]

In this system SMEs applied to the financial intermediaries that granted the micro credit part, while the state-owned body decided on the grant after that. The loan and grant part of the financing were inseparable, so if one of the applications was rejected, it meant the automatic rejection of the whole finance. The loans were disbursed first (which pre-supposes that the relevant application for grant has been approved and an assistance document has been issued). These 2 institutions had to evaluate different aspects of the project, and shared the risks and used different IT solutions without united workflow and database.

\footnotetext{
22 or 20 million HUF

${ }^{23}$ Nyikos (2016) Financial Instruments for Better Public Spending - Implementing Mechanisms and Effects In: 24th NISPAcee Annual Conference: Spreading Standards, Building Capabilities: European Administrative Space in Progress. Forumi Shqiptar Social Ekonomik (ASET), 2016. p. 22. 22 p
} 
In the 2014-2020 period $60 \%$ of all ESI Funds will be dedicated to economic development and job creation and with an allocation of EUR 2.3 billion, Hungary is almost tripling its allocation to financial instruments compared with 2007-2013. The use of FIs will be expanded to R\&D\&I, energy, ICT and the social economy. [17,18,24]

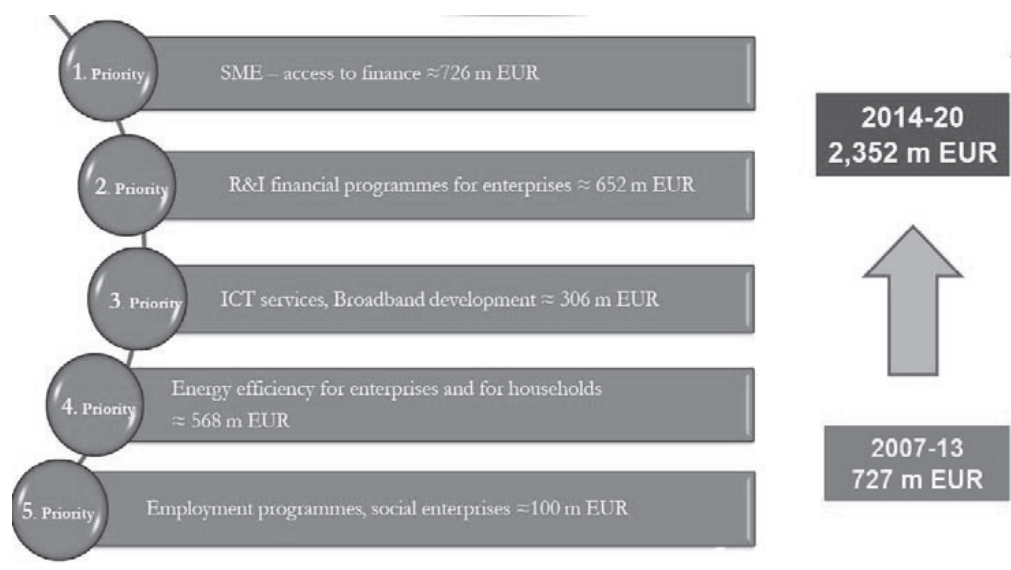

Figure 4: Indicative proportion of financial instruments in EDIOP

Source: Ministry of National Economy 2016 [18, 24]

In Hungary the planned financial instruments are i) credit, leasing and factoring, ii) combined products, iii) venture capital programmes and iv) guarantee instruments. Based on the positive experience Hungary intends to continue the use of combined financial instruments (loan and grant) in several thematic areas (SME, ICT, R\&I, energy efficiency). [18, 24]

However because of the new legal interpretation of the European Commission on the selection of financial intermediaries ${ }^{24}$ Hungary had to change the 2007-2013 FI institutional system. Hungary as a result of several open calls - worked with a widespread external intermediary network in the case of JEREMIE. [11] With the use of public procurement only one winner is possible, even if it is a consortium. The managing authority and the holding fund manager decided to select an intermediary network by public procurement process instead of procuring intermediaries per FIs ${ }^{25}$. The consortium has to provide dedicated bank branches working as access points for standardized financial products using EU sources. [23]

\footnotetext{
${ }^{24}$ According to the European Commission's new legal explanation, because the Management Authority has to comply with the general principles as well, including when selecting bodies implementing financial instruments: they must comply with applicable law, in particular on state aid and public procurement and the selection of financial intermediaries has to be in line with public procurement law.

25 Still the PP procedure for the selection of financial intermediaries may potentially decrease in many ways the efficiency of the implementation of financial instruments, because amendments to terms and conditions of financial instruments during the implementation-period (potentially 15 years) cannot be handled under inflexible service contract conditions and it could cause significant implementation issues for private investors and final recipients.
} 


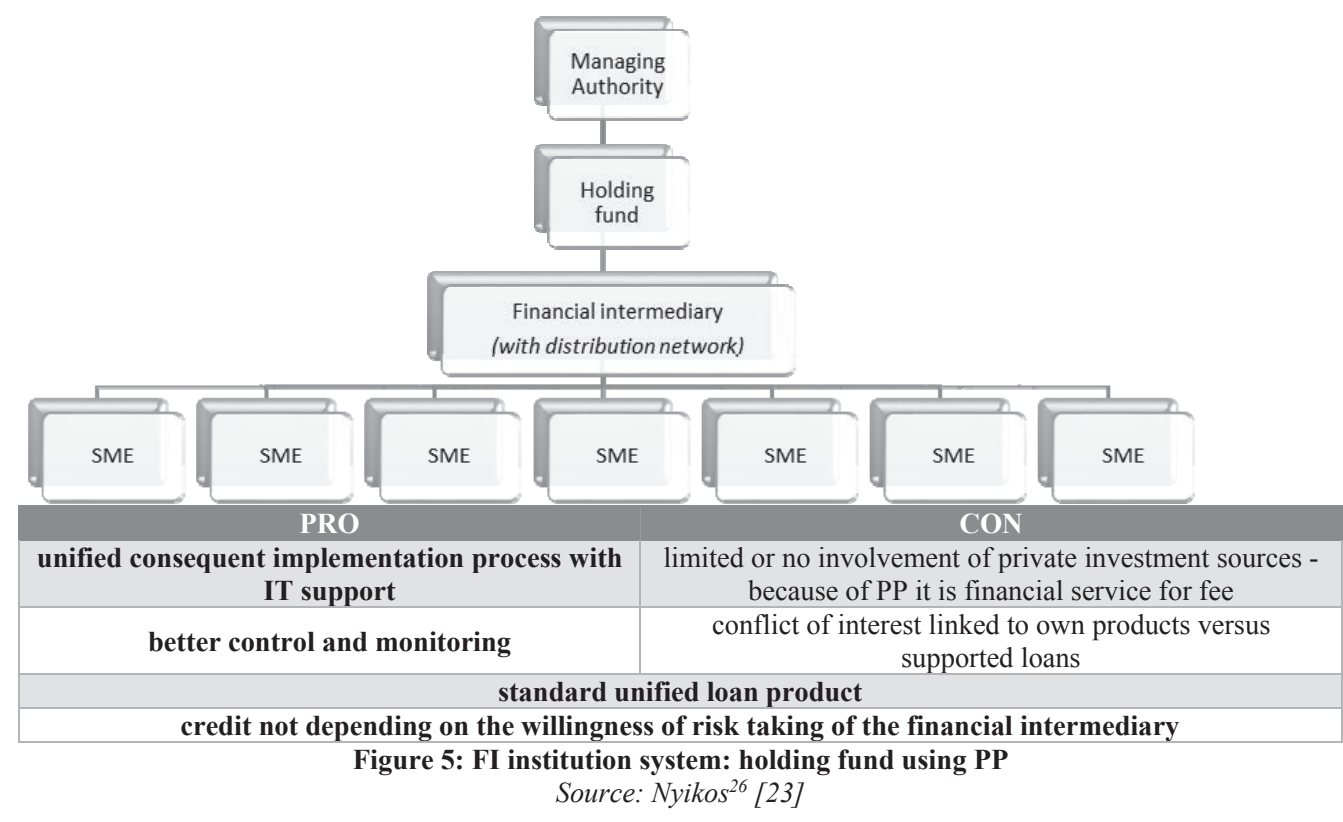

Although this new situation caused several obstacles, it made also possible to consider establishing a united integrated IT system for more effective and efficient implementation process for combined solutions, as described in the following sections.

\section{Integrated solution for combined loans}

For the 2014-2020 programming period the basic principle remained: in the combined tools the loan (managed by the financial intermediary) and the grant (managed by the MA) belong together and cannot be separated. However, for a more effective and less time consuming process to be in place the two sides should work parallel. Regarding the IT support of combined products a completely new approach is being applied in the current period. In the previous period applications were submitted personally by final recipients and management tasks were carried out in different IT systems. The new IT solution is based on two main elements: the eCohesion concept and the integration of business workflows. These changes are driven by the objective of the reduction of administrative burdens.

As the concept of the combined projects was driven by the fact that they would finance single operations, thus these would not support separate operations with distinct eligible costs, but the same eligible costs of a selected operation, therefore consistency of rules and procedures between the two systems had to be created in order to reduce administrative burden and costs. In this context the following challenges had been identified:

- $\quad$ review and consolidation of the process of project assessment tasks on both sides, namely the managing authority and the financial intermediary, in order to avoid duplication of tasks,

${ }^{26}$ Nyikos (2016) Financial Instruments for Better Public Spending - Implementing Mechanisms and Effects In: 24th NISPAcee Annual Conference: Spreading Standards, Building Capabilities: European Administrative Space in Progress. Forumi Shqiptar Social Ekonomik (ASET), 2016. p. 22. 22 p 
- $\quad$ harmonization of eligibility criteria set by the managing authority for grants and the eligibility criteria set by the holding fund manager for granting support from financial instruments,

- consolidation of the application data required from the applicants in line with the above mentioned aspects.

Despite the experience gained from the previous period to respond to these challenges, it took 9 months for the managing authority, the body implementing the fund of funds and the IT team ${ }^{27}$ to establish a functioning IT system for combined projects. The two main reasons for this delay were that, all parties had to review their own rules and procedures and by doing so, they had to abandon old, unreasonable habits of institutional heritage (e.g. limited publicity of selection criteria in the case of financial instruments). Secondly, although it had been obvious at the very beginning, that the implementation systems of grants and financial instruments differ in many ways, it was quite shocking how crucial difficulties as a consequence may occur (e.g. investments that are to be supported through financial instruments shall not be physically completed or fully implemented at the date of the investment decision, while managing authorities of grants not only allow for, but very often use retrospective financing).

In line with the Hungarian implementation rules, Gov. Decree No. 272/2014, project evaluation consists of two main phases:

- $\quad$ eligibility assessment of the applicant and of the project proposal,

- technical assessment of the project proposal in accordance with the selection criteria.

As a rule of thumb, the managing authority was made responsible for the eligibility assessment of the operations, as majority of the eligibility criteria set by both parties proved to be similar in line with the governing cohesion policy implementation and state aid rules and thus, duplicate assessment could be avoided. . [5, 6, 7, 8, 13]

However, some eligibility criteria remained specific for the financial instruments, i.e.

- whether the applicant has tax debts or is subject to debt settlement proceedings and whether the applicant has any arrears of any past financial transactions (as these factors indicate a low level of willingness for repayment), and

- $\quad$ whether the proposed operation consists of physically completed or fully implemented parts (as this would be discrepant with the overall purpose of financial instruments, namely hat financial instruments shall support investments which do not give rise to sufficient funding from market sources).

Technically it means that the financial intermediaries examine the eligibility criteria linked to the above mentioned aspects only, besides they perform a credit scoring for assessing the qualification for the loan and for determining the creditworthiness of the applicant and the corresponding loan $\operatorname{margins}^{28} \cdot[2]$

\footnotetext{
${ }^{27}$ despite the close cooperation and the weekly Task Force meetings

28 in line with "Communication from the Commission No. 2008/C 14/02 on the revision of the method for setting the reference and discount rates"
} 
Therefore only those project applications that qualify as eligible by the managing authority and by the financial intermediaries with respect to the above mentioned criteria can be further assessed.

Due to the above mentioned fact, the dominance of the management authority in the process, a single document of call for proposal is used for combined projects, which thematically follows the template that is used for grants. However, specific building blocks were added for financial instruments, e.g.

- a commitment period for the loan - the period in which the loan can be disbursed - was defined and set generally to 12 months, beginning from the physical completion of the operation,

- $\quad$ specification of the grace period,

- terms of repayment,

- $\quad$ specification of acceptable forms of guarantees etc.

Some terms of financing had to be harmonized between grants and financial instruments (e.g. conditions relating to a property affected by the development) too. These differences were based on the fact that the Hungarian Development Bank as holding fund manager is using its own terms and rules for loans that are based on banking conventions.

Furthermore, as a single call for proposal is used for combined projects, a single application form was created. This application form consists of all data that is necessary from the beneficiary for the assessment of qualifying for the loan and the grant. For the set-up this form had to align the data needs of both parties due to over-lapping. This process covered not only the selection of duplicate data, but an accurate specification of data formats as IT systems run with pre-defined data checking and any deviation may have caused a blocking of the IT data processing processes. In some cases, data transformations resulted in partial reprogramming of the IT system used for financial instruments. Anyway, this task was worthwhile and necessary as it substantially reduced the administrative burden of beneficiaries.

Regarding the technical assessment of the process it was necessary to lay down a strict demarcation of tasks between the parties. According to that, financial intermediaries perform the examination of the collateralization and viability-check of the project (the latter is carried out by cash-flow calculations based on estimated data provided by the applicant). All other assessments (compliance with the operational programme, contribution to thematic objectives, relevance and constitution of project budget etc.) are carried out by the managing authority. It is also important to mention that managing authorities use a ranking among project proposals according to the selection criteria, while financial intermediaries do not rank the projects; they only decide whether the project proposal is up to the mark according to the collateralization- and viability-check. This system not only reduces the number of iterations between the managing authority and the financial intermediary, but also eliminates the possibility of inconsistent results of technical assessment, which would require the involvement of a third party for making a final decision.

However, an iteration step could not be avoided. As the calculation of state aid completely differs between the two regimes, it is the financial intermediary who makes a first decision during the technical assessment: if the project is viable and collateralization is adequate, the financial 
intermediary calculates (taking into account the results of collateralization and the result of creditworthiness of the eligibility assessment) the amount of state aid of the loan, notifies the managing authority, which then assesses whether the project budget (loan + grant) complies with aid intensity rules. If the reduction of the budget is necessary, the managing authority proportionally reduces the amount of grant and loan as well, and based on its proposal, the financial intermediary makes a final credit decision on the reduced loan.

Based on the final credit decision, the managing authority makes its final decision on the project proposal with regard to the grant. This means that a project will be financed only, if both parties give the green light.

During the contracting and payment processes both parties follow their own rules of procedures. Therefore, the financial intermediaries enter into a loan contract and the managing authority enters into a contract for the grant with the beneficiary. However, the main parameters of the projects cannot be modified by the beneficiaries in the interval between the positive decisions on the project and concluding the contracts.

Payment requests will be submitted by the beneficiaries to the managing authority, which examines the original copies, while financial intermediaries examine electronic copies of that. Both parties follow their own rules of eligibility of payments. As soon as both parties approved the payment request and the corresponding amount, payment instalments will be financed proportionally to the loan-grant ratio of the project by both parties according to their own procedures. This means that the beneficiaries receive two money transfers for the same eligible cost. This also means that loan is not paid in advance, but together with the grant, which is usually disbursed ex-post.

\section{4. eCohesion: a new perspective}

According to the concept of the new IT solution applicants can submit a single application form only electronically using a one-stop-shop portal (https://eptk.fair.gov.hu/) to apply for combined loans. This online portal has been available since 2014 and it serves to support the management of all types of EU funded projects. On this portal, applicants can register a single funding account and manage all their projects with this account.This solution is based on the implementation of the eCohesion concept which can significantly contribute to the efficiency of funding procedures.

In 2010 the European Commission initiated an Action Programme to simplify administrative requirements and eliminate unnecessary administrative burdens on businesses, small businesses in particular. Cohesion policy was one of the priority areas of the Action Programme with an estimated $24 \%$ reduction of administrative costs. According to arguments of experts this level of reduction could be realised by the provision of interactive portal services where beneficiaries can submit all necessary information electronically. This concept contributes to the improvement of efficiency which is the main driver of the reduction of burdens.

Following the above recommendations, the Commission launched an initiative focusing on the reduction of administrative burdens of cohesion policy and also rural development policy by the provision of electronic data exchange services via online portals. The initiative was labelled as "eCohesion" addressing a wide range of legal, procedural, organisational factors. [14]

Regulation 1303/2013 of the European Parliament and of the Council specifies the three fundamental components of e-Cohesion. The provision of electronic data exchange services, 
interoperability and the implementation of the only once encoding principle ensure the reduction of administrative burdens. [5]

Electronic data exchange services allow the electronic exchange of documents and data, including audiovisual media supports, scanned documents and electronic files. Pursuant to the above regulation Member States shall ensure that all exchanges of information between beneficiaries and the relevant authorities can be carried out by means of electronic data exchange systems.

Regulation 1011/2014 prescribes that electronic data exchange systems shall be equipped with at least the following functionalities: interactive forms and/or forms prefilled by the system, automatic calculations, automatic embedded controls which reduce repeated exchanges of documents or information, system-generated alerts, online status tracking. These functions are directly linked to the reduction of burdens and the issue of efficiency. [9]

As regards the "only once encoding" principle, data and documents regarding a single development project shall be shared and re-used by the authorities involved in the management of the same development programme. The relevant authorities cannot ask for the same data repeatedly. The application of the principle minimises multiple information requests and facilitates the reduction of administrative burdens by streamlining business workflows. [5]

The application of the principle is based on the cooperation of relevant authorities, so it is strongly interlinked with interoperability. Interoperability can be defined as "the ability of disparate and diverse organisations to interact towards mutually beneficial and agreed common goals, involving the sharing of information and knowledge between the organisations, through the business processes they support, by means of the exchange of data between their respective ICT systems". Henceforth, interoperability is not simply a technological issue. It requires the cooperation of authorities at legal, organisational, semantic and technical levels. [3]

The case of combined products clearly exemplifies the importance of these levels. The managing authority and the financial intermediary had to consider all these levels to realize a successful cooperation. The two organisations need to implement the same government decree (legal), they had to review and streamline business procedures (organisational), harmonize financial terms (semantic) and started the development of an integrated IT solution (technological).

The fundamental components of eCohesion are strongly connected to the issue of efficiency. According to the study of the Commission and Deloitte, eCohesion portals at their highest level of sophistication can reach $8 \%$ per annum reduction of administrative burdens. [15]

\section{The integration of grant and loan management workflows}

Driven by the concept of eCohesion final recipients have to use a one-stop-shop portal which is technically an online portal automatically synchronizing with the grant management system used by the managing authority. Since grant management and banking procedures both have a rather specific nature, accordingly the managing authority and the financial intermediaries use specialized IT systems to manage grant-specific and loan-specific sub-procedures. The relevant data of loanspecific workflows are taken to the loan management system of the intermediaries.

However, following the only once encoding principle the financial intermediaries also need to interact via the eCohesion portal with the recipients, so the management workflows of the two 
parties had to be integrated. To keep specific workflows on the same track, main procedural information and decisions are entered in the managing authority system by both parties. To make the cooperation of the actors seamless, they are notified by email alerts on each other's' actions to trigger upcoming workflow steps.

The applied solution is based on the process analysation and synchronization showed before and depicted by Figure 6.

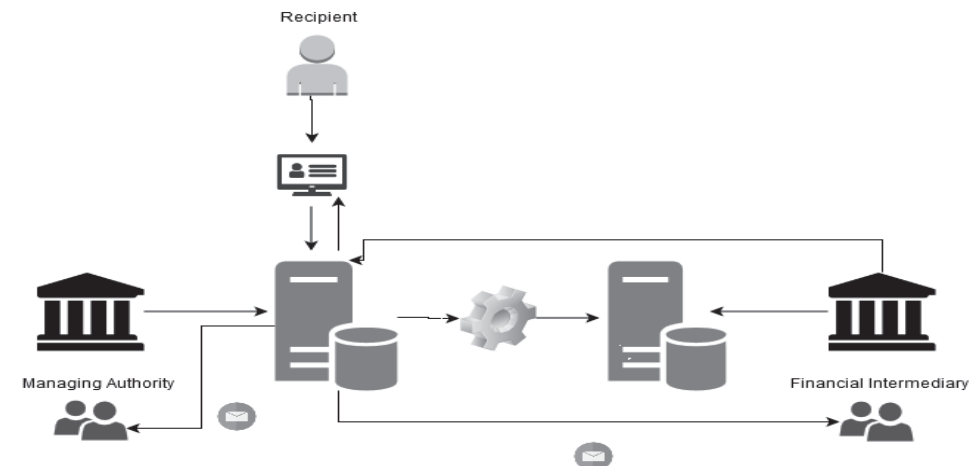

Figure 6: IT systems and business workflows in the 2014-2020 period Sources: Authors

The implementation of the complete IT solution has several phases. The first phase covers the procedure of project selection, and its portal functionality has been available since January 2017. The planning of further phases covering other business procedures is in progress at the time of the publication of this paper.

The integration procedure had three main challenges: the type of data transfer between the two systems; the definition of a common workflow and the notification of the two parties on the actions of each other. Taking into consideration the differences between the two IT systems, the complexity of possible solutions and the given deadlines to launch the first combined calls, automatic and complete data synchronization was not an option, so the development team adopted a specific approach. They decided to establish a one-way data interface which transmits the main application data to the system of the financial intermediaries. These are the data needed for assessment procedures.

As business procedures of the two parties were harmonized, many procedural steps can be carried out in parallel. Nevertheless, at crucial procedural points, parties have to wait for each other. Firstly, certain procedural decisions cannot be passed without the results of specific procedures on the other side. Secondly, several interactions with the recipient (correction request, clarifying questions) can be realized only once so they should be based on the information needs of both organizations. Based on these requirements the two parties need to be notified of the completion and the results of actions on the other side. The above one-way data interface cannot support this kind of information exchange, however.

This dilemma was resolved by granting access for the financial intermediaries to relevant functions in the grant management system. Besides, certain dedicated functions for intermediaries were developed, where they can enter and save the main results of their relevant actions. The usage of these relevant functions always triggers notifications to inform the other on the completion of 
preceding actions. These measures provide a solution for sharing information between the two organisations.

\section{Conclusion}

Following the new conditions given by the new cohesion regulation and the European Commission legal interpretations, the demand for the uniform standards and management methods of the new FIs is pushing the structure in several cases (also in the case of Hungary) to different solutions from what were used before. This new direction could be an effective solution. However, even with the change of the FI architecture the incorporation of experiences is very important, the need for expertise and administrative capacity is crucial. Accordingly, the challenges to be faced require higher and high-qualified management resources in order to mitigate risks and accomplish the goals set out by the policy plans.

Setting up financial instruments and an implementation system of combined products take long time and effort, in Hungary even with experience of implementation in these kinds of tools it took 9 months to establish a functioning implementation system. In the context of the Hungarian system of combined projects, financial instruments are still treated as complementary financial resources. This approach is also evidenced in the way how the tasks of combined projects' assessment have been allocated between the managing authorities dealing with grants and the financial intermediaries dealing with loans. In this sense, financial intermediaries are rather like subsidiaries. The main advantage of the new system is, however, that it allows for a preparation for future expectations that is the domination of financial instruments in SME financing, by making beneficiaries and managing authorities more experienced.

Compared to the practice of the previous period, the Hungarian integrated solution can place the management of combined products on a higher level of maturity. The eCohesion-based management has a great potential to eliminate unnecessary burdens and provide a flexible tool for recipients without timely and geographical limits. The main lesson learned is that the application of the one-stop-shop approach triggers the rationalization of business procedures and the integration of IT workflows. This redesigning of the process can also contribute to a further reduction of burdens.

\section{References}

[1] EUROPEAN COMMISSION, Commission Regulation (EU) No 1998/2006 on on the application of Articles 87 and 88 of the Treaty to de minimis aid, in: Official Journal of the European Union, Bruxelles, 2006.

[2] EUROPEAN COMMISSION, the revision of the method for setting the reference and discount rates; (2008/C 14/02), Bruxelles, 2008.

[3] EUROPEAN COMMISSION, European interoperability framework EIF) for European public services (Pages 1, 2), in: Official Journal of the European Union, Bruxelles, 2012.

[4] EUROPEAN COMMISSION, Regulation (Eu, Euratom) No 966/2012 of the European Parliament and of the Council of 25 October 2012 on the financial rules applicable to the general budget of the Union and repealing Council Regulation (EC, Euratom) No 1605/2002; "financial instruments" means Union measures of financial support provided on a complementary basis from the budget in order to address one or more specific policy 
objectives of the Union. Such instruments may take the form of equity or quasi-equity investments, loans or guarantees, or other risk-sharing instruments, and may, where appropriate, be combined with grants", in: Official Journal of the European Union, Bruxelles, 2012.

[5] EUROPEAN COMMISSION, Regulation (EU) No 1303/2013 of the European Parliament and of the Council of 17 December 2013 laying down common provisions on the European Regional Development Fund, the European Social Fund, the Cohesion Fund, the European Agricultural Fund for Rural Development and the European Maritime and Fisheries Fund and laying down general provisions on the European Regional Development Fund, the European Social Fund, the Cohesion Fund and the European Maritime and Fisheries Fund and repealing Council Regulation (EC) No 1083/2006., in: Official Journal of the European Union, Bruxelles, 2013.

[6] EUROPEAN COMMISSION, Commission Delegated Regulation (EU) No 480/2014 of 3 March 2014 supplementing Regulation (EU) No 1303/2013 of the European Parliament and of the Council laying down common provisions on the European Regional Development Fund, the European Social Fund, the Cohesion Fund, the European Agricultural Fund for Rural Development and the European Maritime and Fisheries Fund and laying down general provisions on the European Regional Development Fund, the European Social Fund, the Cohesion Fund and the European Maritime and Fisheries Fund., in: Official Journal of the European Union, Bruxelles, 2014.

[7] EUROPEAN COMMISSION, Commission Regulation (EU) No 651/2014 on declaring certain categories of aid compatible with the internal market in application of Articles 107 and 108 of the Treaty (GBER).,in: Official Journal of the European Union, Bruxelles, 2014.

[8] EUROPEAN COMMISSION, Commission Implementing Regulation (EU) No 964/2014 of 11 September 2014 laying down rules for the application of Regulation (EU) No 1303/2013 of the European Parliament and of the Council as regards standard terms and conditions for financial instruments., in: Official Journal of the European Union, Bruxelles, 2014.

[9] EUROPEAN COMMISSION, Commission implementing regulation (EU) No 1011/2014 laying down detailed rules for implementing Regulation (EU) No 1303/2013 of the European Parliament and of the Council as regards the models for submission of certain information to the Commission and the detailed rules concerning the exchanges of information between beneficiaries and managing authorities, certifying authorities, audit authorities and intermediate bodies, in: Official Journal of the European Union., Bruxelles, 2014.

[10] EUROPEAN COMMISSION, An Investment Plan for Europe; COM(2014) 903 final, Bruxelles, 2014.

[11] EUROPEAN COMMISSION, Guidance for Member States on the selection of bodies implementing FIs, including funds of funds., Bruxelles, 2015.

[12] EUROPEAN COMMISSION, Investing in jobs and growth - maximising the contribution of European Structural and Investment Funds, COM(2015)639final, 14.12.2015, Bruxelles, 2016. 
[13] EUROPEAN COMMISSION, Mid-term review/revision of the multiannual financial framework 2014-2020; $\operatorname{COM(2016)~} 603$ final, Bruxelles, 2016.

[14] EUROPEAN COMMISSION, COCOF note on financial engineering instruments from (COCOF/07/0018/01), (COCOF 08/002/03), (COCOF 10/0014/004), (COCOF 10/0014/05), Bruxelles, 2007-2010.

[15] EUROEAN COMMISSION, Draft opinion of the High Level Group, Administrative burden reduction; priority area Cohesion Policy, second opinion - eCohesion Policy (Pages 3-5), Brussels 2011. Viewed 5 January 2017, [online]. http://ec.europa.eu/smartregulation/refit/admin_burden/docs/120430_opinion_ecohesion_en.pdf

[16] EUROEAN COMMISSION, eGovernance study at EU / Member State level, Draft final report by Deloitte, (Pages 14 - 15, 48), Brussels 2012 . Viewed 5 January 2017, [online]. http://ec.europa.eu/agriculture/external-studies/2012/e-\%20government/fulltext _en.pdf

[17] EUROPEAN COMMISSION, Partnership Agreement for Hungary, 2014-2020, Bruxelles, 2014.

[18] EUROPEAN COMMISSION, Hungarian Economic Development and Innovation OP 20142020, Bruxelles 2015.

[19] EUROPEAN COMMISSION, Hungarian Economic Development Operational Programme 2007-2013. CCI number: 2007HU161PO001, Bruxelles, 2007.

[20] EUROPEAN COMMISSION, Central Hungary Operational Programme 2007-2013. CCI number: 2007HU162PO001, Bruxelles, 2007.

[21] EUROPEAN COMMISSION, Regional Development Operational Programmes 2007-2013, Bruxelles, 2007.

[22] NYIKOS, The Role of Financial Instruments in Improving Access to Finance, Combined Microcredit in Hungary EStIF 2|2015.

[23] NYIKOS, Financial Instruments for Better Public Spending - Implementing Mechanisms and Effects In: 24th NISPAcee Annual Conference: Spreading Standards, Building Capabilities: European Administrative Space in Progress. Forumi Shqiptar Social Ekonomik (ASET), p. 22. 22 p., 2016.

[24] NYIKOS, Research for REGI Committee - Financial instruments in the 2014-20 programming period: First experiences of Member States, European Union, 2016. 